\title{
Recurrent Childhood Anaplastic Large Cell Lymphoma
}

National Cancer Institute

\section{Source}

National Cancer Institute. Recurrent Childhood Anaplastic Large Cell Lymphoma. NCI

Thesaurus. Code C115357.

The reemergence of anaplastic large cell lymphoma in childhood after a period of remission. 